\title{
Clinical characteristics and treatments outcomes in elderly patients with multiple myeloma: A multicenter retrospective study
}

\section{Multipl myelomalı yaş॥ı hastaların klinik karakterleri ve tedavi sonuçları: Çok merkezli retrospektif çalışma}

\author{
Hatice Terzi ${ }^{1}$, Serdal Korkmaz ${ }^{2}$, Ilhami Berber ${ }^{3}$, Muzaffer Keklik², Mehmet Hilmi Dogu ${ }^{4}$, Mehmet \\ Sencan ${ }^{1}$, Emin Kaya ${ }^{5}$, Bulent Eser ${ }^{6}$, Ismail Sari", Osman Ilhan ${ }^{7}$
}

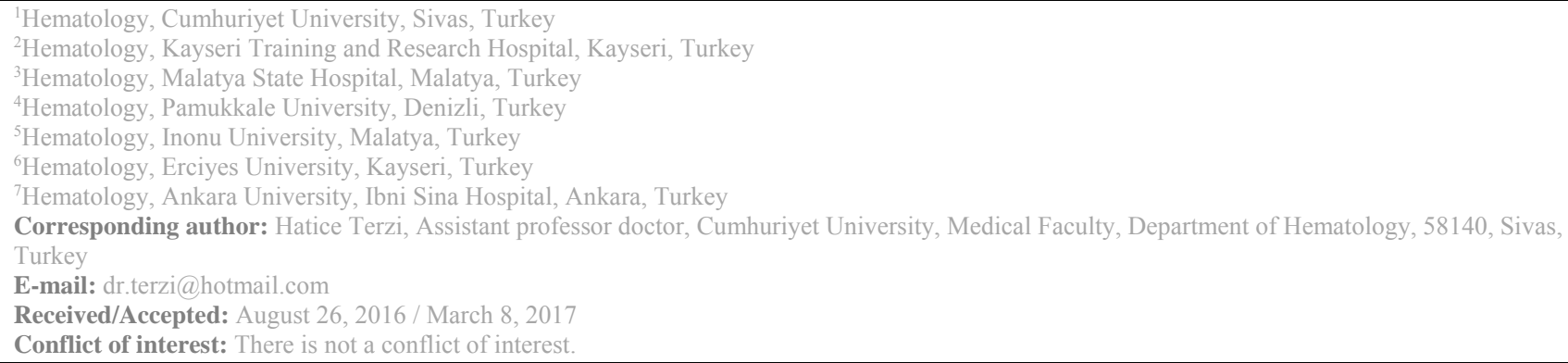

\section{SUMMARY}

Objective: Multiple Myeloma is an incurable fatal disease accounts for $1 \%$ of all the cancer and $10 \%$ of the haematological malignancies. Generally, it is seen in elderly population. The aim of the present study was to present our experience in 106 Multiple Myeloma patients aged 65 years or older and treated with different regimens during the 5 years term preceding the study.

Method: In order to analyse the clinical characteristics and therapeutic outcomes of the Multiple Myeloma patients over 65 years, data were gathered retrospectively from 5 different centres in Turkey.

Results: A total of 105 elderly Multiple Myeloma patients (aged 65 years or older) composed of 51 males and 54 females were evaluated retrospectively. Vincristine, Adriamisin, Dexamethasone (VAD), Bortezomib, Cyclophosphamide, Dexamethasone (VCD), Melphalan, Prednisolone (MP) Melphalan, Prednisolone, Thalidomide (MPT) regimens were given as the first line. 29 patients yielded complete responses and 18 of these patients underwent autologous stem cell transplantation. In 46 patients out of those not yielding a full response were treated with bortezomib, lenalidomide and thalidomide based second line treatments. 29 of those treated with a second line treatment yielded a complete response and 20 of these patients underwent autologous stem cell transplantation. 16 patients not responding to the first and second line treatments were treated with a third line treatment using a lenalidomide based $(n=10)$ and thalidomide based ( $n=6)$ regimens. 5 patients were subjected to autologous stem cell transplantation due to remission status.

Conclusions: An optimal treatment approach should make a productive, safe and high quality life possible while the aim should be to ensure a disease-free survival and prolong the general survival along with obtaining a full response.

Keywords: Autologous stem cell transplantation, Elderly patients, Haematological malignancies, Multiple Myeloma, Optimal treatment.

\section{ÖZET}

Amaç: Mutipl Myeloma, tüm kanser tiplerinin \%1’ ini, hematolojik malignitelerin ise \%10’ unu oluşturan tamamen kürün sağlanamadığı fatal bir hastalıktır. Genellikle yaşlı populasyonda izlenir. Bu çalışmanın amacı, son 5 yılda farklı rejimlerle tedavi edilen 65 yaş ve üzerindeki 105 Mutipl Myeloma’ lı hastadaki klinik deneyimimizi sunmaktır. Yöntem: 65 yaş üzerindeki Mutipl Myeloma'lı hastaların klinik karakterleri ve terapötik sonuçlarını analize etmek için, Türkiye'deki 5 farklı merkezden retrospektif olarak veriler topland1. 
Bulgular: 51 erkek ve 54 kadından oluşan toplam 105 yaş1 Multipl Myeloma hastası (65 yaş ve üzeri) retrospektif olarak değerlendirildi. Hastalara ilk basamak olarak, VAD( vinkrsitin, adriamisin, deksametazon), VCD ( Bortezomib, siklofosfamid, deksametazon), MP( melphalan, prednizolon), MPT (Melphalan, prednizolon, thalidomid) rejimleri verildi. 29 hastada tam yanıt elde edildi ve bu hastaların 18 'ine otolog kök hücre nakli yapıldı. Tam yanıt elde edilemeyen 46 hastaya, ikinci basamak tedavi olarak bortezomib, lenalidomid ve talidomid bazlı rejimler verildi. İkinci basamak tedavi ile tedavi edilenlerin 29 'unda tam yanıt elde edildi ve bu hastalardan 20'sine otolog kök hücre nakli yapıldı. 16 hastaya ise birinci ve ikinci basamak rejimlere yanıt vermediğinden lenalidomid bazlı rejimler (n:10), talidomid bazlı rejimler (n:6) verildi. Bu tedavilerle remisyona giren 5 hastaya Otolog kök hücre nakli yapıldı.

Sonuç: Optimal tedavi yaklaşımı, verimli, güvenli, kaliteli yaşam sağlamalı ve amaç tam yanıtın yanı sıra hastalıksız sağ kalımı ve genel sağ kalımı uzatmak olmalıdır.

Anahtar sözcükler: Otolog kök hücre nakli, yaşlı hastalar, Hematolojik maligniteler, Multipl Myeloma, Optimal tedavi

\section{INTRODUCTION}

Having a $\geq 10 \%$ plasma cell infiltration in the bone marrow, monoclonal protein with any concentration and presence of hypercalcemia, renal insufficiency, anemia and lytic bone lesions (CRAB symptoms) are the main features of symptomatic Multiple Myeloma (MM) ${ }^{1,2}$. MM accounts for $1 \%$ of cancer cases and $10 \%$ of heamatologic malignancies. The median age at diagnosis is 70 years while the two-thirds of the patients with MM is over 65 years. During the last decades, the survival of patients with MM has increased substantially ${ }^{3-5}$. Nearly $90 \%$ of the patients with MM complain about severe demineralization, osteoporosis and multiple destructive bone lesion and secondary symptoms caused by bone diseases such as pathological bone fracture ${ }^{6}$. In MM, areas rich in bone marrow such as skull, spine, sternum vertebrae, pelvis and hip bone are involved the most frequently. On the other hand, $30 \%$ of the cases have been found to have jaw involvement ${ }^{7,8}$.

For more than 40 years, a combination of Melphalan and prednisone (MP) has been the conventional treatment for elderly patients with MM. On the other hand, the advantages of MP treatment are the chance of oral administration and good tolerability. In young patients, novel agents such as thalidomide, bortezomib and lenalidomide are used together with high- dose therapy and autologous stem cell transplantation (ASCT). Besides, a marginal benefit has been observed in patients older than 65 years ${ }^{9}$. However, ASCT remains to be the standard of care inMM) patients aged $<65$ years.

During the past 10 years, advances in newer targeted agents, introducing the proteasome inhibitors and immunomodulatory agents to the myeloma armamentarium, have led to shifting from chemotherapy and ASCT to these agents in standard care.

In the present study, our aim was to present the clinical characteristics and treatment management in MM patients aged 65 years or older.

\section{MATERIAL AND METHODS}

The records of 105 elderly patients $(\geq 65 \mathrm{yr}$ ) followed up for MM between February 2005 and June 2013 at the Hematology Department of Cumhuriyet University, Inönü University, Pamukkale University, Erciyes and Ankara University were evaluated retrospectively. The diagnosis of MM was made on the criteria of DurieSalmon (DS) and the International Myeloma Working Group ${ }^{10}$. The patients were staged according to the DS staging system and the international staging system (ISS) ${ }^{11,12}$. All the routine laboratory, radiologic and pathologic analyses of the patients were studied too. The first attendance of a patient to the haematology department was regarded as the date of diagnosis while the last attendance or the date of death was recorded as the last control.

Patients failing to attend the hematology clinic were contacted by phone. In case of having no answer, the relatives of the patients were asked whether the patient was alive or not. The treatment decisions were made based on the current guidelines taking into account the comorbidities and the performance status of the patient (Barthel daily living index and Eastern Cooperative Oncology Group performance status) ${ }^{13-15}$. After the treatment protocols were completed, urine immunofixation electrophoresis was used to determine the patient's response according to the criteria of the International Myeloma Working Group ${ }^{10}$. Cytogenetic risk stratification was not done as cytogenetic analyses were not available at our hospital.

\section{Statistical analysis}

The data obtained from this study were loaded into the program SPSS (ver: 22.0), and the data were presented with descriptive statistics and frequency distribution tables.

\section{RESULTS}

A total of 105 cases aged 65 years or older and diagnosed with MM were included in our study. The files of the cases were evaluated 
retrospectively. The average age of participants composed of $51(48,6 \%)$ males and $54(51,4 \%)$ females was 71 years (range 65-87). Plasma cell ratio in bone marrow was $10 \%$ or above in all patients while serum protein electrophoresis showed $\mathrm{M}$ band in the $\gamma$ region in $85 \%$ of the patients. The sMM types determined by serum immunofixation electrophoresis were IgG Kappa (40\%), Ig G Lambda (19,06\%), IgA Kappa $(13,34 \%)$, IgA Lambda (12,38\%), IgM (1,9\%), Kappa myeloma (6,67\%), Lambda myeloma
$(3,8 \%)$ and non-secretory myeloma $(2,85)$, respectively. Demographic data of the patients are given in table 1 while the laboratory data at the time of diagnosis are given in table 2 . Based on the international staging system, $21 \%$ of the patients were stage I, $37 \%$ were stage II and $42 \%$ were stage III. Based on Durie-Salmon staging system, 21\% were $1 \mathrm{~A}, 33.5 \%$ were $2 \mathrm{~A}, 3.8 \%$ were $2 \mathrm{~B}, 39 \%$ were $3 \mathrm{~A}, 2.87 \%$ were $3 \mathrm{~B}$ while there was no patient having a stage $1 \mathrm{~B}$ disease.

Table 1. Demographic data of patients with multiple myeloma

\begin{tabular}{lll}
\hline & $\mathrm{N}$ & $\%$ \\
\hline Gender & & \\
Female & 54 & 51.4 \\
Male & 51 & 48.6
\end{tabular}

ISS

$\begin{array}{lll}\text { Stage } 1 & 22 & 21\end{array}$

$\begin{array}{lll}\text { Stage } 2 & 39 & 37\end{array}$

$\begin{array}{lll}\text { Stage } 3 & 44 & 42\end{array}$

\section{Durie-Salmon Stage}

$\begin{array}{lll}1 \mathrm{~A} & 22 & 21 \\ 1 \mathrm{~B} & 0 & 0 \\ 2 \mathrm{~A} & 35 & 33.5 \\ 2 \mathrm{~B} & 4 & 3.8 \\ 3 \mathrm{~A} & 41 & 39 \\ 3 \mathrm{~B} & 3 & 2.87\end{array}$

\begin{tabular}{lll} 
MM type & & \\
IgG Kappa & 42 & 40.00 \\
IgG Lambda & 20 & 19.06 \\
IgA Kappa & 14 & 13.34 \\
IgA Lambda & 13 & 12.38 \\
IgM & 2 & 1.90 \\
Kappa & 7 & 6.67 \\
Lambda & 4 & 3.80 \\
Non secretory & 3 & 2.85 \\
\hline
\end{tabular}


Table 2. Laboratory characteristics of the patients with Multipl Myeloma

\begin{tabular}{|c|c|c|}
\hline Lab. & $\mathrm{X} \pm \mathrm{SD}$ & (Min-Max) \\
\hline $\mathrm{Hb}(\mathrm{g} / \mathrm{dL})$ & $10.25 \pm 1.80$ & $(6.70-15.90)$ \\
\hline WBC $(103 / \mathrm{u})$ & $6.23 \pm 2.88$ & $(0.42-19.00)$ \\
\hline $\operatorname{PLT}(103 / \mathrm{u})$ & $210.35 \pm 101.45$ & $(16.00-546.00)$ \\
\hline BUN (mg/dL) & $26.13 \pm 16.05$ & $(9.00-98.00)$ \\
\hline Cre (mg/dL) & $1.54 \pm 1.52$ & $(0.50-9.00)$ \\
\hline $\operatorname{ALT}(\mathrm{mg} / \mathrm{dL})$ & $22.64 \pm 21.32$ & $(4.00-176.00)$ \\
\hline $\operatorname{AST}(\mathrm{mg} / \mathrm{dL})$ & $26.13 \pm 25.84$ & $(10.00-250.00)$ \\
\hline LDH (U/L) & $206.63 \pm 82.85$ & $(89.00-506.00)$ \\
\hline T. Prt (g/dl) & $8.55 \pm 2.12$ & $(1.00-13.90)$ \\
\hline Albumin (g/dl) & $3.16 \pm 0.71$ & $(1.10-4.70)$ \\
\hline Uric $\operatorname{acid}(\mathrm{mg} / \mathrm{dl})$ & $5.98 \pm 3.12$ & $(2,30-29.00)$ \\
\hline ALP (U/L) & $95.28 \pm 98.58$ & $(25.00-958.00)$ \\
\hline $\mathrm{Ca}(\mathrm{mg} / \mathrm{dl})$ & $9.12 \pm 1.11$ & $(6.80-14.00)$ \\
\hline $\operatorname{Sedimentation}(\mathrm{mm} / \mathrm{h})$ & $80.60 \pm 38.77$ & $(7.00-156.00)$ \\
\hline $\mathrm{CRP}(\mathrm{mg} / \mathrm{L})$ & $14.51 \pm 35.51$ & $(1.00-278.00)$ \\
\hline B2M (mg/dl) & $7.43 \pm 6.25$ & $(1.70-31.40)$ \\
\hline
\end{tabular}

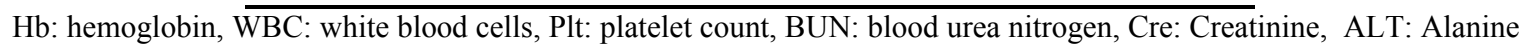
transaminase, AST: Aspartate transaminase, LDH: Lactate dehydrogenase, T.prt: Total Protein, Alb: Albumin, ALP: Alkaline phosphatase, , Ca: Calcium, CRP: C-Reactive Protein, B2M: Beta 2 microglobulin

Of the patients, $68.4 \%(\mathrm{n}=69)$ presented with bone pain while 2 cases had concurrent fracture. $6.9 \%$ $(\mathrm{n}=7)$ of the patients presented with kidney failure and $13.9 \%(n=14)$ had anemia and $3 \%(n=3)$ had infection. 8 patients $(7.9 \%)$ were diagnosed with MM during the routine controls 12 patients $(11.42 \%)$ were followed-up without treatment due to their general poor health. In the remaining 93 patients, VAD (vincristine, adriamycine, dexamethasone), VCD (Bortezomib, cyclophosphamide, dexamethasone), MP (melphalan, prednisolone), MPT (Melphalan, prednisolone, thalidomide) regimens were given as the first line treatment in $51.43 \%, 4.76 \%, 27.62 \%$ and $4.76 \%$ of the patients respectively. $27.61 \%$ $(n=29)$ yielded a full responses and $18(17.14 \%)$ of these patients underwent ASCT. In $46(43,8 \%)$ patients out of those not yielding a full response
(60.95\%, $\mathrm{n}=64), 39.13 \%, 21.74 \%$ and $39.13 \%$ were treated with bortezomib, lenalidomide and thalidomide based second line treatments respectively. $63.04 \%(n=29)$ of those treated with a second line treatment yielded a full response and 17 of these patients underwent ASCT . 16 $(15.23 \%)$ patients not responding to the first and second line treatments were treated with a third line treatment using a lenalidomide based $(\mathrm{n}=10)$ and thalidomide based $(n=6)$ regimens. 5 patients went into remission after these regimens and were subjected to ASCT (Table 3). The said 5 patients were subjected to a second ASCT after relapse. Allogeneic stem cell transplantation was performed in none of the patients. Median general survival rate was found to be 37 months (range 198 months). 70 (68\%) patients are still alive and followed-up regularly. 
Table 3. Treatment regimens received by Mutiple Myeloma patients

\begin{tabular}{lcc}
\hline Treatment protocol & $\mathbf{N}$ & $\mathbf{\%}$ \\
\hline The First-line treatment regimes & 29 & 27.62 \\
MP & 5 & 4.76 \\
MPT & 54 & 51.43 \\
VAD & 5 & 4.76 \\
VCD & 12 & 11.43 \\
$\quad$ No treatment & 105 & 100.00 \\
$\quad$ Total & 29 & 27.61 \\
Remission after first-line treatment & 18 & 17.14 \\
Autologous stem cell transplantation after first-line & & \\
treatment & 18 & 39.13 \\
Second-line treatment regimens & 10 & 21.74 \\
VCD & 18 & 39.13 \\
LD & 46 & 100 \\
TD & 29 & 63.04 \\
Total & 17 & 36.95 \\
Remission after second-line treatment & & \\
Autologous stem cell transplantation after second- & 10 & 62.5 \\
line treatment & 6 & 37.5 \\
tertiary treatment regimens & 16 & 100 \\
$\quad$ LD & 5 & 31.25 \\
TD & 5 & 31.25 \\
$\quad$ Total & 5 & \\
Remission after tertiary treatment & & \\
Autologous stem cell transplantation after tertiary & treatment
\end{tabular}

MP, melphalan 6-9mg/m2/d plus prednisolone $100 \mathrm{mg} / \mathrm{d}$ every $1-5 \mathrm{~d}$ for $28 \mathrm{~d}$; VAD, vincristine $0,4 \mathrm{mg} / \mathrm{m} 2 / \mathrm{d} 1-4 \mathrm{~d}$ plus adriamycin 9 $\mathrm{mg} / \mathrm{m} 2 / \mathrm{d}$ for 1-4 d plus dexametasone $40 \mathrm{mg} / \mathrm{d}$ for 1-4, 9-12 and 17-20d for $4 \mathrm{wk}$; MPT, melphalan 6-9 $\mathrm{mg} / \mathrm{m} 2 / \mathrm{d}$ plus prednisolone $100 \mathrm{mg} / \mathrm{d}$ for $1-5 \mathrm{~d}$ every $28 \mathrm{~d}$; VCD, bortezomib $1,3 \mathrm{mg} / \mathrm{m} 2$ every 1.4 .8 and 11 . d every 3 wk plus cyclophosphamide $50 \mathrm{mg} / \mathrm{d}$ for 1 21d plus dexametasone $40 \mathrm{mg} / \mathrm{d}$ for 1, 2, 4, 5, 8, 9, 11, $12 \mathrm{~d}$ for $3 \mathrm{wk}$; LD, lenalidomide $25 \mathrm{mg} / \mathrm{d}$ for $1-21 \mathrm{~d}$ for $29 \mathrm{~d}$ plus dexametasone $40 \mathrm{mg} / \mathrm{d}$ for 1-4, 9-12, 17-20 d for $4 \mathrm{wk}$; TD, thalidomide $200 \mathrm{mg} / \mathrm{d}$ plus dexametasone $40 \mathrm{mg} / \mathrm{d}$ for 1-4, 9-12, 17-20 d for $4 \mathrm{wk}$;

$\mathrm{N}$, number of patients.

\section{DISCUSSION}

Multiple Myeloma (MM), a disproportionately diagnosed condition in elderly patients, will increase by nearly $80 \%$ in the following two decades due to the aging of the population. More than $60 \%$ of those having MM in the United States are over 65 years and the number of patients diagnosed with $\mathrm{MM}$ is expected to be doubled by 2030. Along with the said expected increase, most of the patients have an advanced stage disease at the time of diagnosis and thus require intervention.

Survival rates have improved dramatically over the last 20 years. However, the improvement in elderly population has not been as great as those in younger adults with MM. Novel therapeutics leading to an improvement in older MM patients should be used carefully by balancing the risk of toxicity with therapy and maintenance of quality of life. Novel instruments such as geriatric assessment tools may help in maintaining the said balance ${ }^{16}$. In elderly patients, the choice of treatment has been a combination therapy with melphalan and prednisone (MP) due to allowing an oral administration in outpatients and having a good tolerability. In our cases, $31.2 \%$ were given MP while $5.4 \%$ received MPT regimen. In MM patients, who are not candidates for tranplant, novel drug protocols based on bortezomib, thalidomide, and lenalidomide have extended the options ${ }^{17}$. In our study, $10.8 \%$ of the patients were treated using bortezomib, lenalidomid, thalidomide as a first line option while the said agents were used as second line in $49.46 \%$ of the patients. A total of $48(45.7 \%)$ patients underwent ASCT. A second ASCT was performed in 5 patients due to relaps. Median general survival rate was found to be 37 months (range 1-98 months) with the available treatments.

In a retrospective analysis carried out by Tarkun $P$. et al., current treatment approaches with bortezomib, thalidomide and lenalidomide have been shown to increase the treatment response and quality of life in MM patients aged 65 years and over ${ }^{18}$. In recent studies, it has been reported a comprehensive geriatric evaluation showing the physical status and sensitivity of a patient would 
help us determine the optimal treatment in geriatric MM patients ${ }^{19}$.

In our study, we evaluated the patients using first the Bartheldaiy living index and then ECOG (Eastern Cooperative Oncology Group) performance status ${ }^{15}$. Those having a daily living activities independent of other people and yielding grade 1-2 in ECOG performance status were given chemotherapy. Briefly, we concluded that MM patients aged over 65 years should be subjected to a geriatric evaluation and undergo ASCT if clinically suitable. Those who are not suitable can be treated with one of the current treatment options with bortezomib, lenalidomid and thalidomide.

\section{CONCLUSION}

The world population is getting older and the number of MM patients over 65 years is increasing. We believe that MM patients over 65 years may undergo ASCT if they are physically fit, and those that are not able to undergo ASCT may be treated with effective current treatments such as thalidomide, bortezomib, lenalidomine along with a supportive care treatment. As a result, an optimal treatment should ensure an effective, safe and high quality life in elderly MM patients. The ultimate aim should be a disease-free survival and prolonged general survival in addition to achieving a treatment response.

\section{Compliance with Ethical Standards Conflicts of interest}

None of the authors of this manuscript has conflict of interest is publishing it.

\section{Human and Animal Rights}

This research does not involve human or animal subject, its merely presentation of a rare entity. Informed Consent Obtained.

\section{REFERENCES}

1. Dimopoulos M, Kyle R, Fermand JP, Rajkumar SV, San Miguel J, Chanan-Khan A, Ludwig H, Joshua D, Mehta J, Gertz M, AvetLoiseau H, Beksaç M, Anderson KC, Moreau P, Singhal S, Goldschmidt H, Boccadoro M, Kumar S, Giralt S, Munshi NC, Jagannath S "Consensus recommendations for standard investigative workup: report of the International Myeloma Workshop Consensus Panel 3" Blood 2011; 117: 4701-5.

2. Van de Donk NW, Lokhorst HM, Anderson KC, Richardson PG. How I treat plasma cell leukemia Blood 2012; 20; 120: 2376-89.

3. Kumar SK, Rajkumar SV, Dispenzieri A, Lacy MQ, Hayman SR, Buadi FK, Zeldenrust
SR, Dingli D, Russell SJ, Lust JA, Greipp PR, Kyle RA, Gertz. Improved survival in multiple myeloma and the impact of novel therapies. Blood 2008; 111: 2516-20.

4. Turesson I, Velez R, Kristinsson SY, Landgren O.Patterns of multiple myeloma during the past 5 decades: stable incidence rates for all age groups in the population but rapidly changing age distribution in the clinic. Mayo Clin Proc 2010; 853: 225-30.

5. Fayers PM, Palumbo A, Hulin C, Waage A, Wijermans P, Beksaç M, Bringhen S, Mary JY, Gimsing P, Termorshuizen F, Haznedar R, Caravita T, Moreau P, Turesson I, Musto P, Benboubker L, Schaafsma M, Sonneveld P, Facon T. Thalidomide for previously untreated elderly patients with multiple myeloma: meta-analysis of 1685 individual patient data from six randomized clinical trials. Blood 2011; 118: 1239-47.

6. Terpos E, Moulopoulos LA, Dimopoulos MA. "Advances in imaging and the management of myeloma bone disease," J Clin Oncol 2011; 10; 29: 1907-15.

7. Rodríguez-Caballero B, Sanchez-Santolino S, García-Montesinos-Perea B, Garcia-Reija MF, Gomez-Roman J, Saiz-Bustillo R."Mandibular solitary plasmocytoma of the jaw: a case report," Med Oral Patol Oral Cir Bucal 2011; 1; 16: e647-50.

8. Seoane J, Aguirre-Urizar JM, Esparza-Gómez G, Suárez-Cunqueiro M, Campos-Trapero J, Pomareda M. "The spectrum of plasma cell neoplasia in oral pathology," Medicina Oral 2003; 8: 269-80.

9. Pulte D, Gondos A, Brenner H. Improvement in survival of older adults with multiple myeloma: results of an updated period analysis of SEER data. Oncologist 2011; 16: 1600-3.

10. Durie BG, Harousseau JL, Miguel JS, Bladé J, Barlogie B, Anderson K, Gertz M, Dimopoulos M, Westin J, Sonneveld P, Ludwig H, Gahrton G, Beksac M, Crowley J, Belch A, Boccadaro M, Cavo M, Turesson I, Joshua D, Vesole D, Kyle R, Alexanian R, Tricot G, Attal M, Merlini G, Powles R, Richardson P, Shimizu K, Tosi P, Morgan G, Rajkumar SV. International uniform response criteria for multiple myeloma. Leukemia. 2006; 20: 1467-73.

11. Bird JM, Owen RG, D'Sa S, Snowden JA, Pratt G, Ashcroft J, Yong K, Cook G, Feyler S, Davies F, Morgan G, Cavenagh J, Low E, Behrens J.Guidelines on the diagnosis and management of multiple myeloma. $\mathrm{Br} \mathrm{J}$ Haematol 2011; 154: 32-75. 
12. Kyle RA, Gertz MA, Witzig TE, Lust JA, Lacy MQ, Dispenzieri A, Fonseca R, Rajkumar SV, Offord JR, Larson DR, Plevak ME, Therneau TM, Greipp PR. Review of 1027 patients with newly diagnosed multiple myeloma. Mayo Clin Proc 2003; 78: 21-33.

13. Rodon P, Linassier C, Gauvain JB, Benboubker L, Goupille P, Maigre M, Luthier F, Dugay J, Lucas V, Colombat P. Multiple myeloma in elderly patients: presenting features and outcome. Eur J Haematol 2001; 6: 11-7.

14. Kumar SK, Mikhael JR, Buadi FK, Dingli D, Dispenzieri A, Fonseca R, Gertz MA, Greipp PR, Hayman SR, Kyle RA, Lacy MQ, Lust JA, Reeder CB, Roy V, Russell SJ, Short KE, Stewart AK, Witzig TE, Zeldenrust SR, Dalton RJ, Rajkumar SV, Bergsagel PL. Management of newly diagnosed symptomatic myeloma: updated mayo stratification of myeloma and risk-adapted therapy (MSMART) guidelines. Mayo Clin Proc 2009; 84: 1095-110.
15. Gary Sinoff G, Ore L. The Barthel Activities of Daily Living Index: Self-Reporting Versus Actual Performance in the Old-Old $(\geq 75$ years). J Am Geriatr Soc 1997; 45: 832-6.

16. Wildes TM, Rosko A, Tuchman SA. Multiple myeloma in the older adult: better prospects, more challenges. J Clin Oncol 2014; 20; 32: 2531-40.

17. Myeloma Trialists' Collaborative Group. Combination chemotherapy versus melphalan plus prednisone as treatment for multiple myeloma: an overview of 6633 patients from 27 randomized trials. Myeloma Trialists' Collaborative Group. J Clin Oncol 1998; 3832-42.

18. Tarkun P, Atalay F, Atesoglu EB, Mehtap O, Simsek M, Terzi E, Geduk A, Balli F, Batman A, Baydemir C, Hacihanefioglu A. Treatment of patients with multiple myeloma over $65 \mathrm{yr}$ : more tolerability or better response? Eur J Haematol 2015; 94: 424-30.

19. Johnson TM. Multiple myeloma treatment and management in the elderly. Consult Pharm 2014; 29: 434-51. 